\title{
IbM PETERNAKAN KAMBING YANG MEMANFAATKAN LIMBAH PEMBUATAN TEMPE JUNREJO BATU
}

\author{
Agus Widarko ${ }^{1}$ dan Nurul Humaidah ${ }^{2}$ \\ ${ }^{1}$ Fakultas Ekonomi Universitas Islam Malang \\ email: aguswidarko@unisma.ac.id \\ ${ }^{2}$ Fakultas Ekonomi Universitas Islam Malang \\ email: nurul humaidah@unisma.ac.id
}

\begin{abstract}
ABSTRAK
Program Iptek bagi masyarakat (IbM) ini bertujuan untuk meningkatkan pengetahuan dan keterampilan kelompok peternak kambing dalam berbagai aspek produksi dan manajemen peternakan kambing secara intensif yang mengacu pada panca usaha peternakan yaitu penggunaan bibit atau bakalan kambing yang unggul, pemberian pakan yang cukup dan berkualitas,perkandangan dan manajemen pemeliharaan yang baik, sistem perkawinan dan perkembangbiakan yang tepat, sistem pencegahan dan pengobatan penyakit dengan benar serta pemasaran produksi yang menguntungkan. Target khusus yang ingin dicapai dalam program IbM ini peternak kambing dapat memanfaatkan limbah industri pembuatan tempe yang difermentasi dahulu untuk meningkatkan kualitas pakan sebagai pengganti pakan konsentrat kambing sekaligus menjaga lingkungan yang asri dengan sistem tiga strata pada lahan pertanian dan pemupukan menggunakan pupuk organikdari kompos kotoran kambing yang menyuburkan tanah. Untuk mencapai tujuan dan target program IbM ini, maka tim pengusul program IbM Unisma menggunakan metode penyuluhan, demo plot fermentasi pakan, reboisasi, pembinaan dan pendampingan usaha. Program IbM ini mendapatkan respon masyarakat peternak kambing yang senantiasa proaktif dalam semua kegiatan penyuluhan, pembinaan, demo plot dan pendampingan usaha. Peternakan kambing telah diusahakan secara terpadu dengan industri tempe yang dimilikinya selama hampir 8 tahun. Pengadaan kambing dibeli dari peternak lain atau pasar hewan tidak diseleksi secara tepat, kandang panggung lantai berlubang sehingga feses tidak mengotori bulu, perkawinan kambing masih inbreeding. Pakan berupa hijauan segar secara ad libitum dan konsentrat limbah pembuatan tempe berupa kulit biji kedelai dan air rendamannya. Pemanfaatan limbah ini dapat meningkatkan PBB kambing sebesar 45 g/ekor/hari dan memberikan Peternak mengaplikasikan ilmu yang diperoleh dengan memperbaiki manajemen produksi peternakan kambing secara intensif menggunakan bahan pakan lokal dari limbah pembuatan tempe dicampur kulit bekatul dan onggok yang difermentasi dahulu agar lebih berkualitas, bergizi dan palatabel yang dapat meningkatkan produktifitas ternak yang berdampak pendapatan dan keuntungan peternak bertambah. Luaran program IbM ini adalah metode fermentasi limbah industri tempe kulit biji kedelai, formulasi pakan konsentrat dari bahan pakan lokal dan artikel jurnal.
\end{abstract}

Kata Kunci: Perfoman kambing, fermentasi, limbah industri tempe. 


\section{PENDAHULUAN Kondisi Usaha Mitra}

Kondisi peternakan kambing milik mitra usaha ini masih menggunakan sistem semi intensif dan pemberian pakan masih mengandalkan ketersediaan hijauan pakan seperti rumput, tanaman ramban, leguminosa pohon dan daun semak pahitan yang tumbuh liar di pematang, lahan kosong dan pinggir jalan yang belum dibudidayakan dengan baik. Kambing jarang diberikan pakan konsentrat sehingga pakan yang dikonsumsi belum memenuhi kebutuhan nutrien untuk hidup pokok dan pertumbuhan sehingga produktivitas masih rendah. Potensi kambing cepat berkembang, pertumbuhan dan produksi karkas tinggi bahkan kualitas daging berlemak disukai konsumen sebagai masakan gule dan sate meningkatkan stamina kejantanan. Ditinjau dari sisi gizi pakan, kambing mampu mentolerir pakan berserat kasarlebih $15 \%$ dan protein kasar kurang dari 14\% (Ensminger, Oldfield danHeinemann, 1990). Apabila manajemen pemeliharaan kambing secara intensif, maka berpeluang sebagai usaha agrobisnis yang menghasilkan keuntungan besar disebabkan harga kambing relatif murah terjangkau bagi masyarakat ekonomi menengah ke bawah.

Topografi lokasi mitra usaha termasuk wilayah altitude tinggi, tanah tegal tadah hujan, hijauan pakan terutama ramban dari tanaman pohon berlimpah, suhu dan kelembaban $65-70 \%$, curah hujan cukup dan air dari sumber yang sangat mendukung untuk pengembangan peternakan kambing. Pemeliharaan kambing di mitra ini hanya sebagai usaha sambilan dan tabungan hidup yang bisa dijual sewaktu-waktu dengan jumlah kepemilikan berkisar 7-15 ekor/ peternak. Hasil observasi tim pengabdi terkini pada bulan Februari tahun 2014 menunjukkan bahwa kondisi peternakan kambing milik mitra usaha ini cukup membanggakan, kandang yang digunakan sistem panggung permanen terbuat dari kayu dan bambu, atap genteng dan semua dinding tidak rapat sehingga kandang tidak panas dengan kelembaban yang tepat. Lantai kandang dari kayu yang berlubang sehingga feses langsung dapat keluar dan di bawah kandang panggung disediakan kubangan penampungan dan setiap 3 bulan sekali kotoran dikumpulkan dan dibuang di kubangan tidak tertutup berfungsi untuk pengomposan alami tanpa atap sehingga kepanasan dan kadang terikut oleh air hujan. Hal ini sebaiknya dibuat pupuk kompos dan sebelum pengomposan feses perlu dikeringkan dan digiling sehingga homogen ukurannya menghasilkan pupuk organik yang harganya mahal. Kandang disekat untuk memisahkan antara indukan, pejantan, dara, dan cempe, hal ini dapat menghindari perkawinan yang tidak diinginkan, keguguran dan resiko kematian ternak kambing akibat perkelaian, kaki kecepit, terpeleset dan lainnya.

Strategi dalam pemberian pakan hijauan tidak dipotong-potongsehingga pakan banyak tercecer, selain itu belum mempertimbangkan kualitas dan kandungan nutrien bahan pakan, serta seharusnya ada kombinasi hijauan terutama leguminose seperti kaliandra, lamtoro dan daun turi serta limbah 
tanaman kacang sehingga diharapkan ada efek suplementari nutrien dalam pakan. Ada beberapa peternak sesekali memberikan comboran pakan konsentrat berupa bekatul, kulit biji kedelai atau pollard dengan jumlah satu ember untuk 3-4 ekor. Performan produksi kambing cukup baik dan bulu halus serta kotorannya lebih kering. Menurut tukang kandang kambing menyukai hijauan ramban seperti lamtoro, kaliandra, daun gamal, daun turi, waru hijau, daun nangka dan daunan pohon lain.

Harga kambing bervariasi tergantung jenis kelamin dan umur atau besar kecilnya tubuhnya, indukan dan dara lebih mahal daripada pejantan. Menurut pemilik mitra usaha, harga kambing indukanperanakan etawah mencapai Rp. 1.550.000, sedang pejantan dewasa yang besar berkisar antara Rp.1.750.000, sampai Rp. 2.500.000,-. Harga jual kambing murah terjangkau banyak kalangan masyarakat sehingga permintaan kambing qurban dari tahun ke tahun meningkat, selain itu anakan yang terus bertambah dengan rataan kelahiran pada kambing sampai 3 kali beranak dalam 2 tahun dengan little size 1-2 per kelahiran. Eksistensi keberadaan mitra peternakan kambing ini bermakna dan berdampak positif terhadap lingkungan sekitar dapat meningkatkan kesuburan tanah karena pembuangan feses kambing dapat digunakan untuk memupuk lahan pertanian dan lahan sekitar sedang urin diatur sedemikian rupa sehingga tidak berbau atau mencemari lingkungan karena di samping kandang dibuatkan tempat buangan kotoran ternak dan sisa pakan yang ditumpuk begitu saja belum ditangani secara baik. Selain itu dari aspek ekonomis, adanya usaha peternakan kambing milik kelompok peternak ini banyak menyerap tenaga kerja yang dapat mengurangi pengangguran di pedesaan serta mendatangkan tambahan pendapatan. Di balik itu apabila pengambilan tanaman ramban seenaknya tanpa ada upaya reboisasi tanaman pohon maka lingkungan peternakan yang awalnya hijau banyak tanaman ramban akan menjadi gundul, tanah rentan terjadi erosi dan udara panas (Tillman, Hartadi, Reksohadiprojo, Prawirokusumo dan Lebdosoekojo, 1989).

Kegiatan reboisasi sebaiknya dilakukan pada sepanjang jalan raya atau lahan keritis dan tanaman pagar pada lahan pertanian. Selain itu pengadaan pakan hijauan dapat dilakukan dengan menerapkan penanaman terpadu dengan sistem tiga strata di lahan pertanian dengan tanaman ramban seperti pohon nangka, kaliandra, glirisida, lamtoro sebagai tanaman pagar dan di dalamnya tanaman umbi-umbian sedang dan bagian lebih dalam tanaman pangan seperti jagung, padi dan kacang tanah yang limbahnya nanti untuk pakan hijauan. Untuk menjaga kesuburan tanah sebaiknya tidak sering dipupuk anorganik, sebaiknya diberi pupuk organik feses kambing dan harus melakukan kombinasi penanaman hijauan leguminosa dan non leguminose dan tidak tanaman pangan yang sama secara terus menerus sehingga tanah kekurangan unsur hara tertentu. 


\section{Permasalahan yang Dihadapi Mitra}

Tim pengabdi telah melakukan observasi awal ke lokasi peternakan dan wawancara dengan pemilik mitra usaha, maka permasalahan yang dihadapi mitra dapat diidentifikasi sebagai berikut:

- Produksi hijauan pakan tidak mencukupi kebutuhan kambing

- Komposisi dan formulasi pakan yang diberikan tidak tepat

- Stok hijauan pakan musim kemarau kurang mencukupi kebutuhan.

- Kualitas hijauan pakan yang diberikan rendah

- Belum mempunyai alat pencacah hijauan (copper) sehingga pemberian hijauan masih utuh dan banyak tercecer dari tempat pakan.

- Belum memberikan pakan alternatif dari limbah agroindustry okal seperti kulit ari kedelai, bekatul dan konsentrat Jumlah pemberian pakan asal kenyang saja, belum ada pertimbangan kualitas dan efisiensi pakan.

- Produksi ternak kurang optimum dan masih menggunakan pupuk anorganik yang mengeluarkan biaya besar

- Pemilihan bakalan dan indukan kambing kurang tepat

- Sistem perkawinanalami dan waktu kurang tepat

- Kandang kambing kotor dan timbul bau kurang sedap

- Belum ada tempat pembuangan kotoran dan sisa hijauan pakan yang dibakar saja, seharusnya dibuat kompos organik

- Penyakit skabies sering menyerang kambing karena lantai kandang kotor

- Ada beberapa kambing pertumbuhan lambat dan kurus

- Penjualan kambing mudah dan lebih mahal

- Proses culling pada kambing yang cacat tidak dilakukan

- Belum ada pemisahan untuk kambing bunting dengan kambing yang lain terutama pejantan belum dewasa mengusik bisa mengakibatkan keguguran

- Belum ada upaya reboisasi tanaman pakan pada lahan kosong dan kritis

\section{TARGET DAN LUARAN Jenis Luaran}

Jenis luaran program IbM ini meliputi model penanaman hijauan pakan menggunakan sistem tiga strata, reboisasi di lahan kritis serta melakukan penanaman tumpangsari sehingga dapat diprediksi produksi hijauan pakan optimal yang dapat mencukupi kebutuhan pakan dan teknologi pengolahan dan pengawetan pakan dengan fermentasi agar kualitas pakan terkontrol. Selain itu target luaran program IbM ini yaitu produk pakan konsentrat dari limbah agroindustri lokal seperti onggok limbah tepung tapioka, kulit ari kedelai dari limbah pembuatan tempe, kulit daging kelapa dari industri parut kelapa pengganti bungkil kelapa, bekatul limbah penggilingan padi, pollard, 
dan ampas tahu ditambah mineral tepung kapur tohor, tepung tulang dan garam dapur.

Penggunaan urea dalam pakan ruminansia dibatasi $2-3 \%$ dan perlu dicampur dengan karbohidrat mudah tercerna untuk mempercepat sintesa protein mikroba (Soebarinoto, Chuzaemi dan Mashudi, 1991). Pembuatan pakan konsentrat diformulasi sebagai berikut: bekatul $35 \%$, pollard $20 \%$, bungkil kedelai $13 \%$, empok jagung $8 \%$, onggok $20 \%$, mineral dan garam dapur 4\%. Menurut Siregar (1990) standar nutrien dalam konsentrat untuk penggemukan kambing protein minimal 16\% dan SK kurang 18\%.

\section{METODE PELAKSANAAN}

\section{Metode Pendekatan untuk Realisasi Program $I_{b} M$}

Untuk merealisasikan program $\mathrm{I}_{b} \mathrm{M}$, maka tim pengusul menggunakan beberapa metode pendekatan: observasi di lapang, wawancara dengan peternak, penyuluhandan pembinaan usaha, demoplot pembuatan produk pakan konsentrat, pelatihan pengolahan pakan dan pengomposan limbah ternak, uji coba produk pakan untuk pakan, mengenalkan alat copper pencacah hijauan pakan untuk efisiensi pakan dan tidak banyak tercecer, kemudian melakukan pendampingan kerja pemeliharaan kambing. Metode penyuluhan mengikuti petunjuk Mardikanto (2009).

\section{Solusi Persoalan Produksi dan Manajemen Usaha}

Tim pengusul pengabdian masyarakat membuat kegiatan sebagai langkah solusi atas permasalahan produksi dan manajemen usaha yaitu:

- Melakukan reobservasi ke lokasi mitra dan wawancara sambil berdiskusi untuk memperjelas permasalahan yang dihadapi mitra usaha.

- Memberikan penyuluhan keseluruhan aspek manajemen pemeliharaan kambing, strategi pemberian pakan, perkawinan dan perkembangbiakan, pencegahan penyakit, analisa usaha dan perbaikan sistem pemasaran.

- Penyediaan bibit tanaman leguminose dan sistem penanaman tumpangsari dengan pola bergilir untuk kesuburan tanah.

- Melakukan reboisasi dengan tanaman pohon sebagai pakan seperti nangka, randu, waru hijau, tanaman turi yang disukai kambing di lahan kosong dan lahan kritis yang berfungsi ganda.

- Memberikan contoh riel cara penanaman leguminosa dan tanaman pangan sistem tiga strata terintegrasi dengan lahan pertanian.

- Fermentasi limbah agroindustri lokal kulit daging kelapa, kulit biji kedelai dan onggok menggunakan bakteri selulolitik menjadi pakan suplemen yang bergizi dan berkualitas.

- Demoplot pembuatan pakan konsentrat yang diformulasi secara tepat sesuai standar sehingga kombinasi dengan hijauan mencukupi kebutuhan. 
- Melakukan pelatihan kerja penyusunan formulasi ransum, pengawetan dan peningkatan kualitas hijauan pakan dengan melakukan demoplot pembuatan hay dan fermentasi hijauan pakan.

- Pengadaan mesin copper pencacah pakan hijauan untuk efisiensi pakan

- Model kombinasi pakan basal hijauan ramban leguminose dan non legum untuk memberikan suplementary effect dan ramban dicopper dahulu sehingga penyajiannya mudah tidak tercecer.

- Penanganan feses kambing untuk pembuatan pupuk kompos organik.

- Pendampingan dan pembinaan para peternak dalam pemeliharaan kambing yang menuju peternakan intensif dan professional.

- Melakukan culling pada kambing pejantan yang cacat, tidak normal menghindari perkawinan yang tidak dikehendaki sekaligus peningkatan pertumbuhan dan pertambahan bobot badan (PBB) kambing yang optimal dengan karkas dan daging yang berkualitas.

- Membuat rekording dan program kalender sistem perkawinan kambinguntuk ketepatan waktu kapan ternak dikawinkan dan beranak sehingga target diharapkan dalam dua tahun kambing dapat melahirkan tiga kali.

- Melakukan analisa usaha dan keuntungan peternakan kambing yang telah diusahakan.

- Melakukan diskusi lingkup pemasaran panenan kambing dan keuntungan.

\section{HASIL YANG DICAPAI}

\section{Sosialisasi dan Persiapan Program IbM}

Tahap pertama, Tim pengabdi melakukan kunjungan ke lokasi untuk perijinan dan sosialisasi program IbM dengan mitra peternak kambing di Junrejo Kota Batu, dan dilanjutkan mengadakan observasi ulang di lapang seperti tampak Gambar 1 dan 2. Kaki kandang terbuat dari batu bata cor sehingga kuat dan aman dari rayap. Tahapan berikutnya tim pengabdi melakukan persiapan kegiatan, inventarisasi kebutuhan materi dan pengadaannya. Pengadaan materi utama meliputi bahan pakan (bekatul, pollard, bungkil kedelai dan mineral) serta limbah agroindustri lokal meliputi kulit daging kelapa, kulit biji kedelai dan onggok KKO untuk difermentasi untuk pemuatan pakan konsentrat kambing, tanaman pangan pohon nangka dan leguminosa untuk reboisasi dan daunnya dimanfaatkan sebagai hijauan pakan dibeli dari pembibit tanaman desa Mulyo Agung, Dau, Kabupaten Malang. 

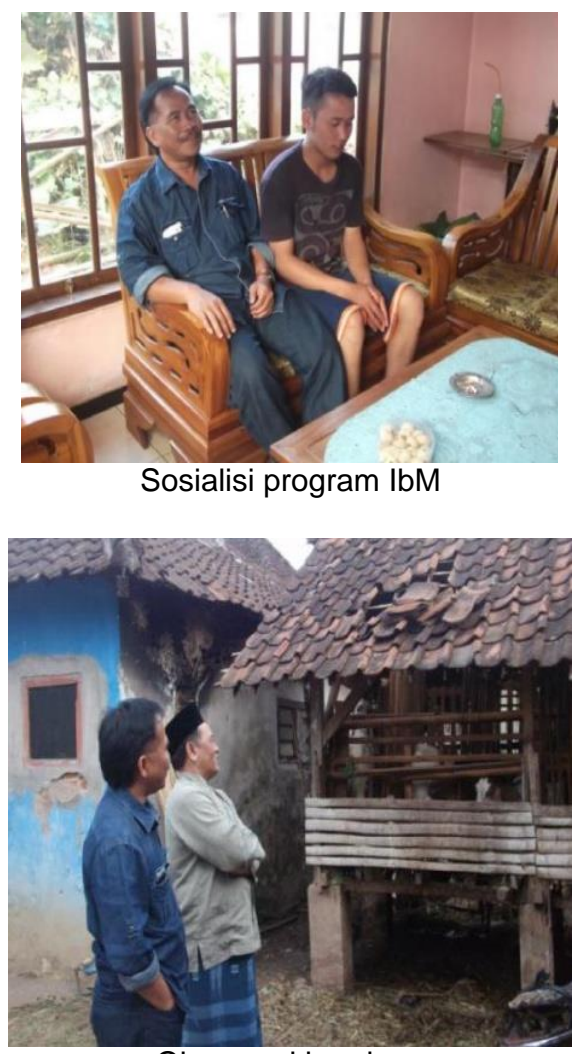

Observasi kandang

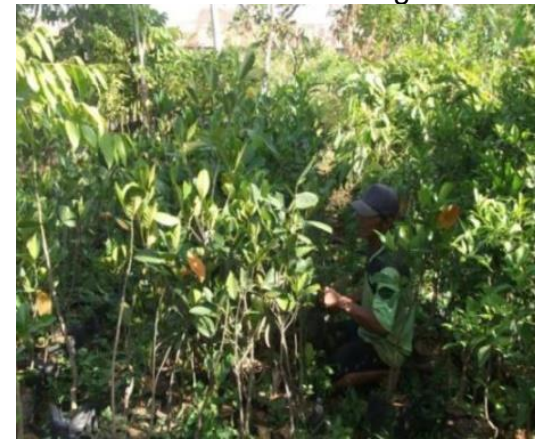

Bibit Tanaman nangka 


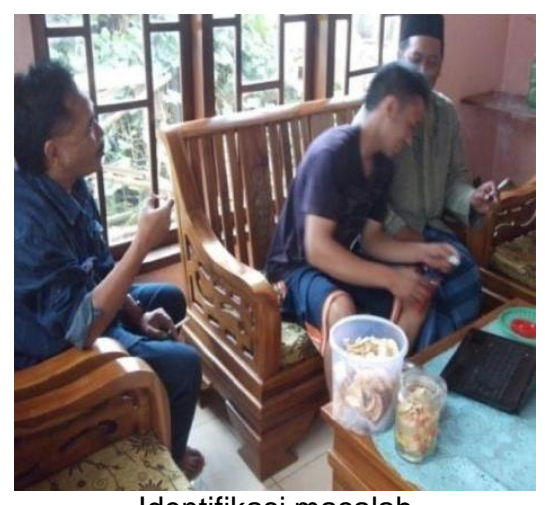

Identifikasi masalah

\section{Penyuluhan Peternakan Kambing}

Kegiatan penyuluhan dan demoplot dilakukan melalui konfirmasi dan koordinasi dengan mitra peternak kambing setempat Junrejo, Kota Batu. Alat bantu untuk penyuluhan yaitu LCD, Laptop, dan kamera untuk dokumentasi. Kegiatan ini dihadiri masyarakat peternak. Pemusatan kegiatan penyuluhan dilakukan di rumah peternak. Waktu pelaksanaan kegiatan penyuluhan dilakukan pada sore hari setelah sholat dhuhur sekitar pukul 14.00 sampai 1600 WIB, hal ini dilakukan dengan maksud tidak mengganggu kesibukan dan tugas pokok masyarakat tani peternak setempat sehingga mudah dikondisikan dengan baik.

Materi penyuluhan yang disampaikan intinya adalah penjabaran tentang faktor-faktor yang mempengaruhi keberhasilan beternak kambing seperti terdapat pada skematis intensifikasi peternakan kambing pada gambar berikut.

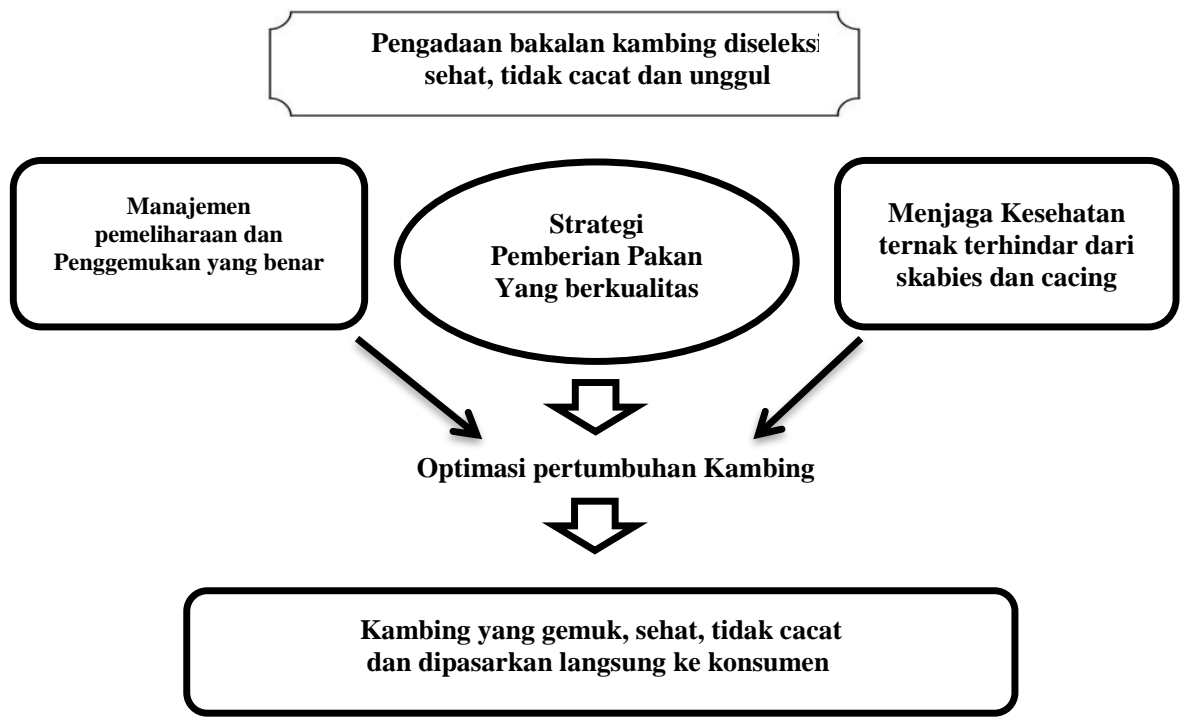


Penyampaian materi penyuluhan ini disertai diskusi dan tukar pengalaman teoritis pengendalian produktivitas ternak antara tim pengabdi dengan peternak mitra. Penyuluhan dilakukan secara massal dan dilanjutkan secara individu pada saat kunjungan lapang untuk memberikan bimbingan dan konsultasi secara personal. Tujuan kegiatan ini adalah untuk meningkatkan pengetahuan dan memberikan motivasi pada peternak untuk melakukan usaha pemeliharaan kambing secara intensif. Adapun panca usaha peternakan meliputi pemilihan dan penggunaan bibit unggul, pemberian pakan bergizi dan jumlah yang cukup, sistem perkandangan dan manajemen pemeliharaan yang benar, sistem perkawinan dan perkembangbiakan yang baik, sistem pencegahan dan pengobatan penyakit dengan benar dan sistem pemasaran kambing yang menguntungkan.

\section{Demo Praktek Fermentasi Limbah kulit kedelai sebagai pakan kambing}

Fermentasi limbah agroindustri lokal dari kombinasi kulit biji kedelai (KBK), bekatul dan onggok dalam kondisi kering udara yang dikombinasikan 40\% : 30\% dan 30\% dengan menggunakan kultur bakteri selulolitik dosis 1 liter untuk 10 kuintal bahan, dikondisikan kadar air 60\%, diaduk merata, dimasukkan dalam gentong dan lama inkubasi 4-7 hari secara anaerob pada suhu ruang sekitar $26-28^{\circ} \mathrm{C}$. Kemudian dilakukan pengambilan sampel bahan untuk dianalisis kandungan nutrien baik sebelum dan sesudah perlakuan fermentasi. Metode fermentasi limbah agroindustri sebagai campuran pakan konsentrat seperti pada Gambar di bawah ini.

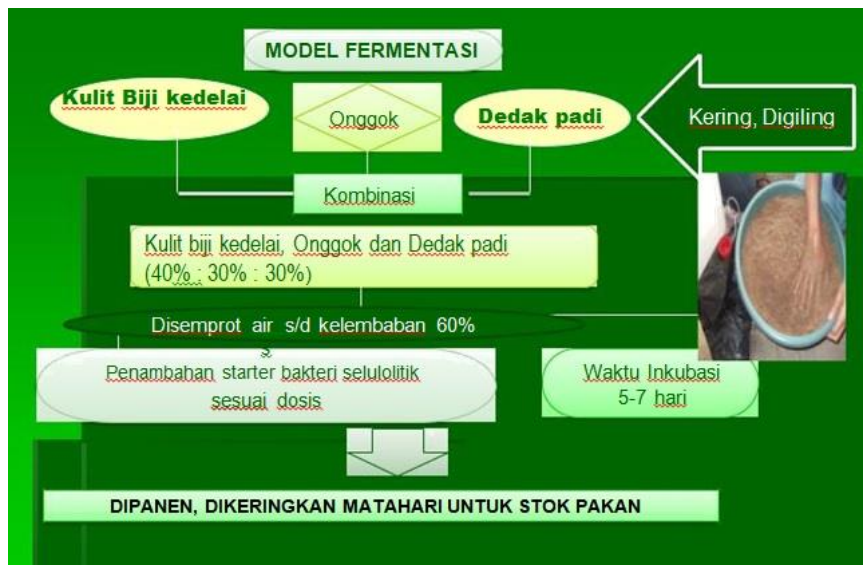

Setelah fermentasi KBO dipanen, kemudian dilakukan pengeringan matahari selama 2-3 hari sampai kandungan kadar air kurang dari $12 \%$ maka produk KBOF ini siap diberikan pada kambing atau disimpan untuk stok bahan pakan kambing hari berikutnya. Bahan pakan yang kering (BK > $86 \%$ ) mempunyai daya simpan lama dan tidak ditumbuhi jamur. Kandungan gizi produk fermentasi KBOF dalam BK, BK 87,5\% ; BO 92,637\% ; PK 11,55\% ; LK 31,29\% ; SK 17,34 \% ; NDF 28,23\% ; ADF 18,33\% ; selulosa 8,89\% dan lignin $7,13 \%$. Hambatan dalam pengadaan pakan fermentasi ini adalah 
pengeringan dengan matahari apabila turun hujan merepotkan sekali karena harus cepat ditutup pakai terpal, apabila sudah kehujanan maka bahan pakan berjamur cepat rusak.

Kulit biji Kedelai diambil dari limbah pembuatan tempe. Hal ini menunjukkan bahwa peternakan kambing sebagai usaha sistem terpadu dengan memanfaatkan limbah pembuatan tempe ini sebagai pakan konsentrat. Selanjutnya proses pembuatan tempe meliputi perendaman, perebusan, pendinginan, pemisahan kulit dengan biji menggunakan mesin, peragian dan pemeraman yang keseluruhannya sampai menjadi produk tempe membutuhkan waktu 2-3 hari. Pengulitan biji kedelai dilakukan dengan cara penggilingan basah pada biji kedelai yang sudah direbus dan dingin setelah perendaman, Kemudian dilanjutkan pengapungan menggunakan air bersih untuk memisahkan kulit dari biji kedelai.
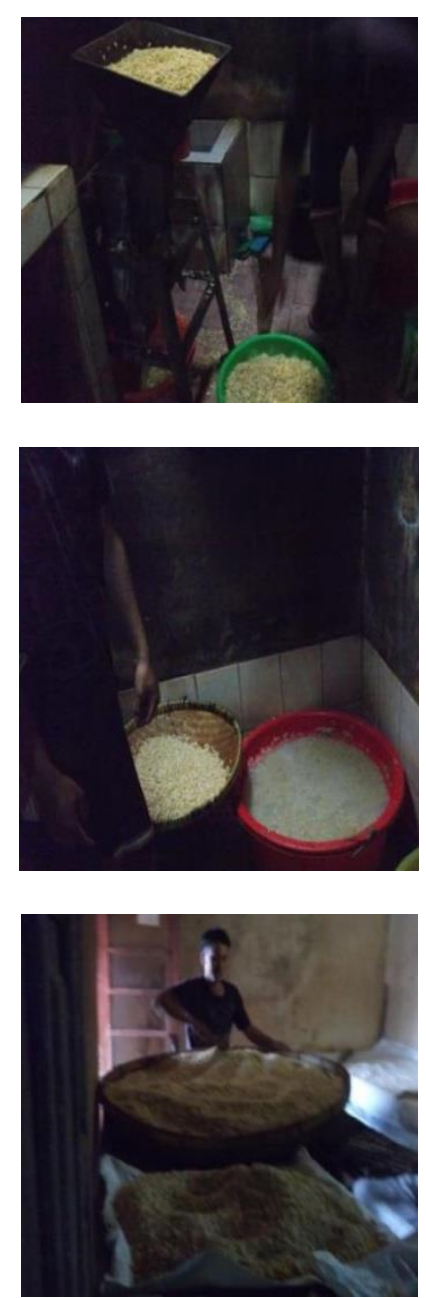

Reboisasi Tanaman Nangka dan Penanaman Sistem Tiga Strata (STS) 
Pengiriman bahan pakan baik pollard, bekatul dan konsentrat dikirim bersama bibit tanaman pangan seperti bibit pohon nangka, sengon dan duren seperti pada Gambar 10. Reboisasi tanaman pohon pangan (nangka, mangga, pepaya, pisang) dilakukan di kebun rumput sekitar kandang, sedangkan tanaman pakan di sepanjang jalan, lahan kosong dan lahan kritis. Reboisasi ini diharapkan menghasilkan buah fungsional mendatangkan tambahan penghasilan bagi peternak dan daunannya dimanfaatkan sebagai hijauan pakan.

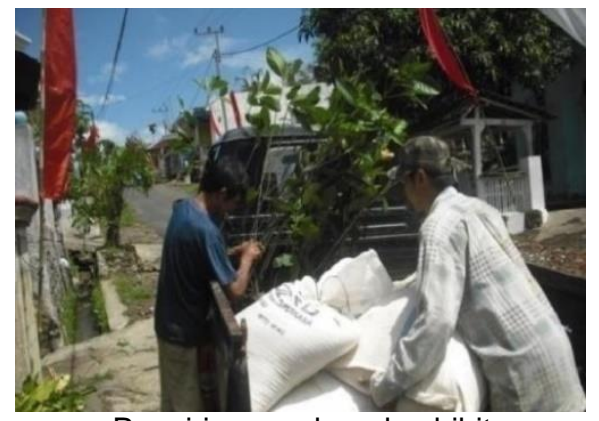

Pengiriman pakan dan bibit

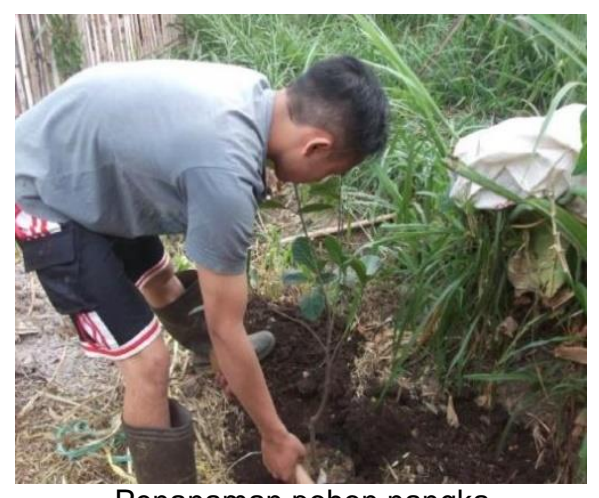

Penanaman pohon nangka

Model penanaman Sistem Tiga Strata (STS) di lahan pertanian diatur sebagai berikut: bagian luar tanaman pagar seperti gamal, lamtoro dan pohon nangka di bagian pojok, bagian dalam tanaman umbi-umbian, sedang bagian paling dalam kombinasi tanaman fungsional jagung, padi dan kacang sebagai tanaman leguminosa yang dapat menjaga kesuburan tanah, model penanaman STS disajikan seperti pada Gambar di bawah ini Bagian luar/pagar (Tanaman gamal, lamtaro,kaliandra dan pohon nangka)

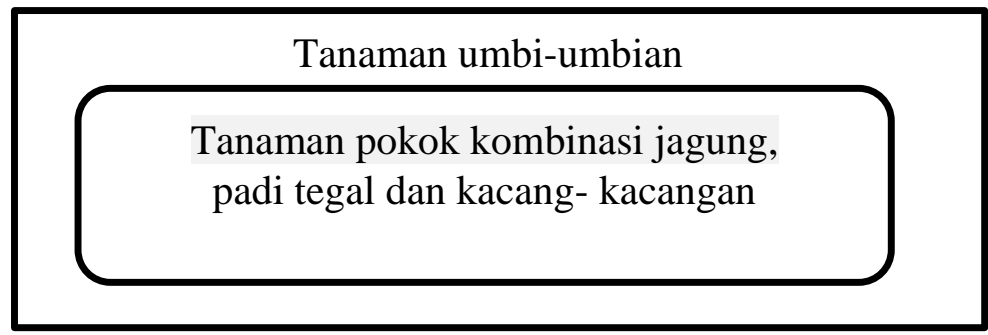


Model reboisasi tanaman fungsional yang produktip direalisasikan dengan cara menanam tumbuhan pangan seperti pohon nangka dan pepaya atau hijauan pakan meliputi kaliandra, gamal, turi, lamtoro atau tanaman pohon di sepanjang jalan dan lahan kritis untuk menjaga kelestraian lingkungan dan penyediaan pakan yang berkualitas. Selanjutnya disarankan untuk pengembangan usaha dengan membangun 1 unit kandang ternak domba peranakan merino yang adaptif dan produktif terletak di belakang kandang kambing seperti pada gambar berikut.
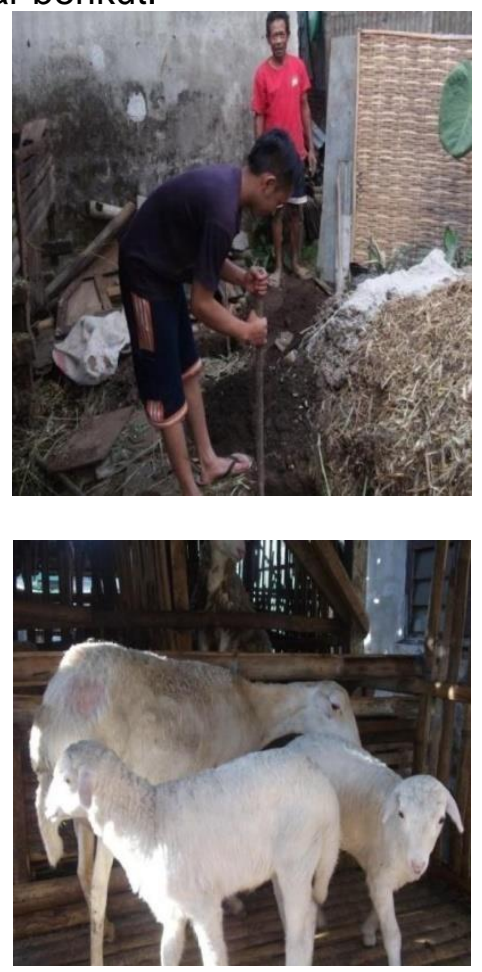

\section{Pemberian Pakan dan Penjualan Kambing}

Pakan yang diberikan pada kambing berupa pakan dasar hijauan dan konsentrat. Hijauan pakan meliputi rumput liar seperti rumput lapang, rumput gajah, pahitan atau tanaman legum limbah kacang dan daun turi diambil dari pematang sawah atau area lahan pertanian tegal yang sedang istirahat tanam. Hijauan pakan dicacah dahulu sebelum diberikan pada kambing. Kambing hampir setiap hari dan sudah terbiasa diberikan pakan konsentrat kulit biji kedelai dari limbah pembuatan tempe dalam kondisi basah ditempatkan pada baki, limbah ini banyak terikut biji kedelai yang pecah dan terapung pada saat pemisahan kulit dan biji kedelai sehingga limbah ini masih bergizi tinggi dan sangat disukai kambing adaptif dan palatabel seperti tampak pada Gambar 15. Sedang air minum yang diberikan berupa air limbah rendaman biji kedelai yang sudah direbus sebelum digiling dan air pengapungan untuk memisahkan biji dan kulit setelah digiling tanpa ditambah 
air lagi langsung disajikan pada kambing dengan pertimbangan air juga dapat dipenuhi dari hijauan rumput segar yang diberikan.
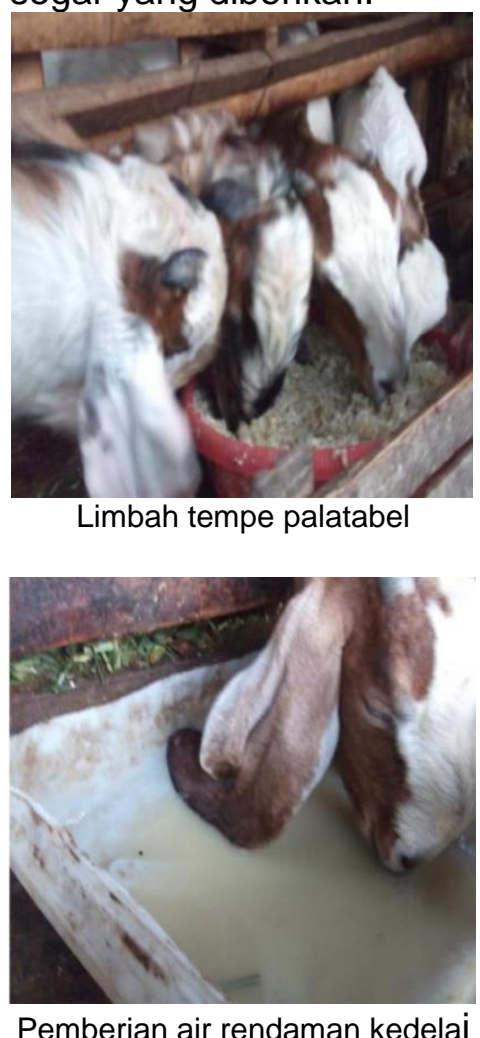

Selama pemeliharan kambing tidak pernah dimandikan, namun bulunya masih kelihatan bersih dan karakter kambing suka manjat seperti terlihat pada Gambar 17, hal ini disebabkan kandangnya dibuat model panggung dengan lantai kayu yang berlubang sehingga kotoran banyak keluar atau turun ke dalam kubangan kolong kandang. Apabila feses ini sudah menumpuk banyak yang tercampur rumput, biasanya setiap 3 bulan sekali dimasukkan ke dalam sak karung tertutup rapat yang secara alami menjadi pupuk kompos untuk ditebar atau dibuang di tegalan yang menyuburkan tanah. Untuk mengatasi agar hijauan pakan tidak tercecer, maka hijauan pakan diberikan dicacah menggunakan mesin copper. 

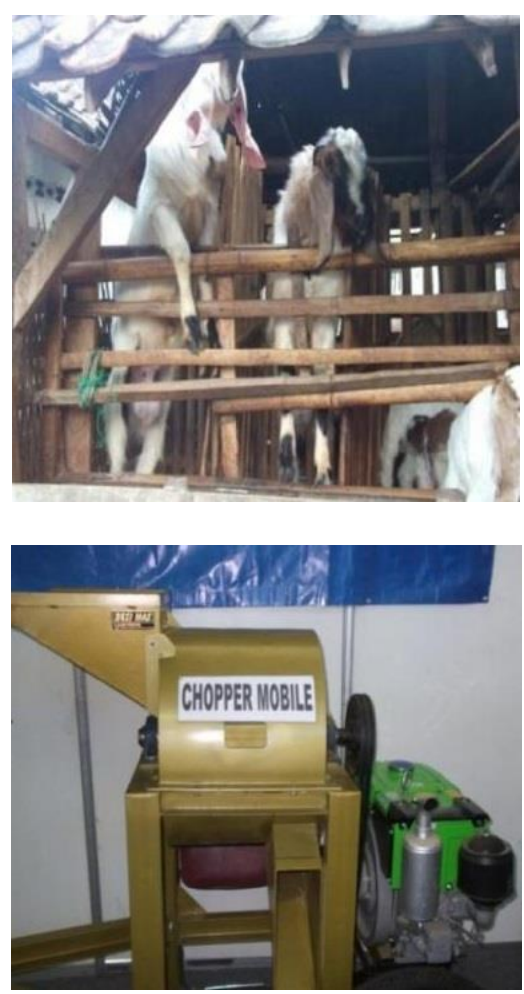

Pemasaran kambing berdasarkan bobot ternak dan jenis kelamin. Semakin besar bobot kambing harganya semakin mahal, demikian juga jenis kelamin jantan lebih mahal dibanding betina. Permintaaan masyarakat tinggi pada kambing untuk walimahan pernikahan, syukuran dan hajatan kematian serta kambing sebagai hewan aqiqohan yang dipotong umur lebih muda minimal 8 bulan dan juga untuk hewan qurban terjangkau masyarakat berpenghasilan rendah. Persyaratan syar'i hewan qurban adalah hewan potong berkaki empat seperti sapi, kerbau, onta, kuda, kambing dan domba yang sehat, tidak cacat dan poel (gigi susu sudah ganti gigi tetap ukurannya lebih besar). Syarat gigi poel ini kuat sekali sehingga jangan sampai niat qurban tetapi hewan qurbannya tidak poel maka pahalanya shodaqoh. Perintah penyembelihan hewan kurban diwajibkan bagi muslim sesuai dengan kemampuan finansial. Di Batu dan Malang raya harga kambing qurban pada tahun 2014 dijual berkisar Rp. 2.500.000,- sampai Rp. 3.750.000,-

\section{KESIMPULAN DAN SARAN}

\section{Kesimpulan}

Program IbM ini mendapatkan respon yang baik dari peternak kambing, peternakan kambing ini diusahakan secara terpadu dengan industri tempe selama hampir 8 tahun. Pengadaan kambing dibeli dari peternak lain atau pasar hewan tidak diseleksi secara tepat, kandang panggung lantai berlubang sehingga feses tidak mengotori bulu, perkawinan kambing masih inbreeding. 
Pakan berupa hijauan segar secara ad libitum dan konsentrat limbah pembuatan tempe berupa kulit biji kedelai dan air rendamannya. Pemanfaatan limbah ini dapat meningkatkan PBB kambing sebesar $45 \mathrm{~g} / \mathrm{ekor} / \mathrm{hari}$ dan memberikan tambahan keuntungan bagi peternak yang bersinergi dengan pengrajin tempe di Kota Batu.

\section{Saran}

Disarankan mitra peternak domba memperbaiki manajemen pemeliharaan yang mengacu pada panca usaha peternakan dan menggunakan pejantan pemacek yang unggul yang tidak inbreeding sehingga produktifitas kambing meningkat. Kulit biji kedelai saat diproduksi melimpah disarankan dikeringkan agar daya simpan lama untuk stok bahan pakan.

\section{DAFTAR PUSTAKA}

Cahyono, B. 2003.Beternak Kambing dan Domba.Kanisius. Yogyakarta Ensminger, M.E., J.E. Oldfield, and W.W. Heinemann. 1995. Feed and Nutrition. The Ensminger Publishing Company, California.

Mardikanto, T. 2009. Sistem Penyuluhan Pertanian. Pusat Pengembangan

Agribisnis dan Perhutanan Sosial. Sebelas Maret University Press.

Surakarta

Soebarinoto, S. Chuzaemi dan Mashudi. 199I. IImu Gizi Ruminansia. Universitas Brawijaya. Animal Husbandry Project Malang.

Siregar, 1990. Makanan Ternak Ruminansia. Penebar Swadaya. Jakarta.

Tillman, A.D., H. Hartadi, S. Reksohadiprodjo, S. Prawirokusumo dan S. Lebdosoekojo. 1989. Ilmu Makanan Ternak Dasar. Fakultas Peternakan Universitas Gadjah Mada. Gadjah Mada University Press. Yogyakarta

Tim Penyusun. 2013. Panduan Pelaksanaan Penelitian dan Pengabdian Kepada Masyarakat di Perguruan Tinggi. Edisi IX. Direktorat Penelitian dan Pengabdian Kepada Masyarakat, Direktorat Jendral Perguruan Tinggi, Kementrian Pendidikan dan Kebudayaan 